\title{
AXIN1 Gene
}

National Cancer Institute

\section{Source}

National Cancer Institute. AXIN1 Gene. NCI Thesaurus. Code C19969.

This gene plays a role in signal transduction and is involved in development. 